\title{
Kegiatan penyiangan koleksi bahan pustaka di perpustakaan perguruan tinggi
}

\author{
Rohmaniyah \\ Mahasiswa Program Studi Interdisiplinary Islamic Studies \\ Pascasarjana Universitas Islam Negeri Sunan Kalijaga Yogyakarta \\ Email : rohmaniyah21@gmail.com
}

\begin{abstract}
This discussion aims to find out the procedures or stages in weeding library materials and the obstacles often faced by librarians when they want to carry out weeding activities in the university library. Descriptive methods are used in this study where this study is limited to studying various literatures related to issues discussed such as procedures and stages that must be carried out in weeding the collection of college libraries.
\end{abstract}

Keywords: Weeding, Collection Development, College Library.

\begin{abstract}
ABSTRAK
Pembahasan ini bertujuan untuk mengetahui prosedur atau tahapan dalam penyiangan bahan pustaka dan kendala yang sering dihadapi pustakawan ketika ingin melaksanakan kegiatan penyiangan di perpustakaan Perguruan Tinggi. Metode deskriptif dipakai dalam studi ini dimana studi ini hanya sebatas mempelajari berbagai literatur yang berhubungan dengan masalah yang dibahas seperti prosedur dan tahapan-tahapan yang mesti dilakukakn dalam penyiangan koleksi perpustakaan perguruan tinggi.
\end{abstract}

Kata Kunci : Penyiangan; Pengembangan koleksi; Perpustakaan perguruan tinggi

\section{A. PENDAHULUAN}

Perpustakaan merupakan suatu ruangan, bagian dari gedung/ bangunan atau gedung itu sendiri yang berisi buku- buku koleksi, yang disusun dan diatur sedemikian rupa, sehingga mudah unuk dicari dan dipergunakan apabila sewaktu- waktu diperlukan oleh pembaca. (Sutarno NS 2003, 7)

Perpustakaan sebagai pusat sumber daya informasi yang menjadi tulang punggung gerak majunya suatu institusi terutama institusi pendidikan, dimana tuntutan untuk adaptasi terhadap perkembangan informasi sangat tinggi. Hal ini dikarenakan pengguna dominan dari kalangan akademisi yang kebutuhannya akan informasi begitu kuat, sehingga mau tidak mau perpustakaan harus pula berfikir untuk berupaya mengembangkan diri guna memenuhi kebutuhan pengguna. (Suwarno 2010, 37)

Pengembangan koleksi merupakan suatu kegiatan dalam mengadakan atau memilih koleksi yang telah ditetapkan kedalam kebijakan pengembangan koleksi agar dapat menemukan titik terang dalam pengembangan koleksi. Perpustakaan menentukan dan memilih macam bahan pustaka yang akan dihimpun menjadi koleksi diperpustakaan. Didalam proses pengembangan koleksi bahan pustaka ada beberapa tahapan kegiatan yang dilakukan yaitu salah satunya adalah penyiangan koleksi bahan pustaka sangat penting 
dalam pengembangan koleksi. Karena penyiangan adalah suatu kegiatan yang dilakukan pustakawan dalam memilih bahan pustaka yang kira-kira sudah jarang atau tidak dipakai lagi oleh pengguna. Apabila dilihat dari pengertiannya ada beberapa pakar yang mencoba memberikan batasan atau definisi. Eleanor Mathews mengartikan penyiangan sebagai suatu pemindahan koleksi dari satu tempat ke tempat lain, pencabutan koleksi dari jajarannya atau menyimpan suatu koleksi ke tempat yang tidak diperuntukkan lagi untuk umum. ( Rusmana, Agustini d, and Winoto 2015, 202)

Dengan kata lain berupaya untuk menyegarkan bagi koleksi yang sudah rusak, yang eksemplarnya banyak, adanya edisi baru, kurang up to date koleksinya, bahasanya kurang dipahami dan masih banyak lagi tipe-tipe koleksi yang ada dirak perpustakaan. Dengan adanya kegiatan penyiangan, koleksi yang sering tidak digunakan oleh pengguna bisa di pisahkan dari rak di perpustakaan, dengan kata lain revolusi koleksi atau mengevaluasi buku yang terlah ada. (Cahyono 2017, 3)

Semakin lamanya bahan pustaka di Perpustakaan di pinjam oleh pengguna, maka bahan pustaka tersebut akan mengalami kerusakan fisik seperti kehilangan beberapa lembar dari halamanya, atau tulisanya sudah sulit dibaca. Ketika hadir koleksi terbaru menyebabkan koleksi lama sudah tidak digunakan lagi oleh pengguna perpustakaan. Meskipun ada beberapa jenis koleksi yang semakin bertambahnya usianya justru semakin tinggi nilainya, misalnya koleksi naskah kuno, buku kesenian dan buku-buku sejarah. Jika masalah ini dibiarkan oleh pustakawan akan menyebabkan penumpukan koleksi di perpustakaan. Padahal tidak semua koleksi tidak diminati atau dapat digunakan oleh pengguna perpustakaan. Untuk itu proses penyiangan bahan pustaka itu sangat penting di perpustakaan dan dituntut untuk memenuhi kebutuhan pemustaka untuk menyediakan koleksi yang lengkap agar pemustaka yang datang ke perpustakaan merasa puas dan tidak kecewa.

Dari pendahuluan di atas maka permasalahan yang akan dibahas dapat dirumuskan sebagai berikut yaitu bagaimana prosedur penyiangan bahan pustaka di Perpustakaan Perguruan Tinggi dan kendala apa saja yang dihadapi pustakawan ketika melaksanakan kegiatan penyiangan bahan pustaka.

\section{B. TUJUAN}

Tujuan utama diadakannya kegiatan penyiangan bahan pustaka adalah untuk bisa menyisihkan koleksi bahan pustaka yang telah tidak terpakai lagi dengan mengkoleksi buku-buku yang baru atau yang sering dipakai atau dipinjam oleh pengguna, akurat, relevan dan dapat menghemat tempat, koleksi perpustakaan menjadi tidak menumpuk di rak, menghemat waktu membuat koleksi menjadi lebih menarik dalam meningkatkan kualitas perpustakaan. Sehingga memberikan kemudahan pada pemakai koleksi, dan memungkinkan staf perpustakaan untuk mengelola koleksi lebih efektif dan lebih efisien.

\section{METODE}

Dalam penelitian ini menggunakan metode penelitian yang bersifat deskriptif tentang kegiatan penyiangan bahan pustaka yang ada di Perpustakaan Perguruan Tinggi dan prosedur penyiangan yang diterapkan oleh perpustakaan perguruan tinggi.

Penelitian ini tidak mencari dan menjelaskan serta menguji hipotesis. Penelitian ini hanya sebatas menguji literatur yanga ada tentang kegiatan penyiangan koleksi bahan pustaka di perpustakaan perguruan tinggi.

Dan juga sumber data dalam makalah ini saya dapatkan melalui berbagai sumber seperti ejournal, tesis, dan buku yang mendukung dalam proses kegiatan penyiangan bahan pustaka. 


\section{KAJIAN TEORI}

\section{Kegiatan Penyiangan (Weeding)}

Penyiangan menurut Lasa HS $(2006,323)$ adalah upaya mengeluarkan sejumlah koleksi dari perpustakaan karena telah dianggap tidak relevan lagi, terlalu banyak jumlah eksemplarnya, sudah ada edisi baru, atau koleksi itu termasuk terbitan yang dilarang. Sehingga koleksi ini dapat ditukarkan dengan koleksi perpustakaan lain, dihadiahkan, atau dihancurkan untuk pembuatan kertas lagi.

Menurut Dictionary of Library and Information Science dalam bukunya Sugana, weeding merupakan proses menentukan koleksi apa saja yang akan ditarik secara permanen dan menentukan kriteria koleksi yang akan disiangkan, khususnya terhadap tumpukan-tumpukan buku yang membuat kapasitas ruang terbatas dan membuat rak menjadi lebih menumpuk. Pada perpustakaan umum biasanya menyiangi secara rutin dengan dasar sirkulasi, sedangkan perpustakaan akademik weeding jarang dilakukan oleh pustakawan. Terkadang hanya dilakukan pada rak-rak buku yang berantakan saja dan bila ada terjadi perubahan kurikulum. Barulah pustakawan melakukan kegiatan penyiangan di perpustakaan. (Rahayu and Rahmah 2013)

Menurut Lasa H.S (2006) menyatakan bahwa, penyiangan (weeding) dilakukan minimal setahun sekali dengan maksud menjaga kesegaran koleksi dan juga mengingat keterbatasan daya tampung suatu gedung perpustakaan. Sehingga buku- buku yang dikeluarkan ini dapat disalurkan kepada lembaga, instansi, perpustakaan lain yang lebih membutuhkan, atau bisa bertukar koleksi antar perpustakaan, dan dapat disalurkan ke pabrik kertas untuk dihancurkan dan selanjutnya dibuat kertas lagi.

Penyiangan koleksi ini berisi tentang Sumber Daya Manusia (SDM) yang akan melakukan kegiatan penyiangan bahan pustaka ialah pustakawan dan staff. Sebelum melakukan kegiatan penyiangan pastinya harus mempunyai pedoman atau acuan yang berisi tentang kriteria koleksi yang ingin di siangi. Dan menggunakan alat bantu dalam menunjang kegiatan penyiangan. Dalm didalamnya membahas langkah-langkah, rangkaian kegiatan atau prosedur yang ingin dilaksanakan. Dan tidak lupa pula harus disepakati oleh semua pustakawan dan staf sebelum melaksanakan kegiatan tersebut.

Ada beberapa kegiatan yang harus dilakukan untuk memulai dalam tatalaksana kegiatan weeding, yaitu:

1. melihat dari perubahan kurikulum, jika adanya perubahan kurikulum maka berubah juga koleksi bahan pustaka di rak.

2. melihat pembahasan yang menarik perhatian masyarakat, dalam koleksi bahan pustaka di rak kita sebagai pustakawan harus sering mengawasi pemustaka, bahan pustaka apa yang sering digunakan oleh pengguna.

3. melihat dari bidang koleksi yang memperoleh banyak kegunaan. Dari berbegai koleksi eksemplar ada beberapa bidang bahan pustaka yang terfavorit dalam kegunaaannya.

4. bidang yang menarik perhatian pemustaka dan ahli tentang hal itu dan didukung oleh sejumlah pengetahuan mengenai bidang tersebut.

5. memilih sebuah rak secara teracak. Mulai dari rak mana saja, sebab weeding akan memberi spasi atau tempat yang luas untuk koleksi yang dibutuhkan.

6. mulailah sejak dini, agar koleksi yang tidak digunakan lagi tidak bertumpuk di rak. (Rahayu and Rahmah 2013)

Proses kegiatan weeding harus sering dilakukan karena semakin lama bahan pustaka tidak melakukan kegiatan weeding maka semakin banyak bahan pustaka menumpuk di rak. Agar terbentuk suatu koleksi yang menunjang suatu program instruksional William Paterson State College, pustakawan ditugaskan untuk memilih bahan pustaka di bidang 
subjek tertentu, dan bertidak selaku koordinator perpustakaan (atau perantara) bagi departemen/jurusan yang mengelola program bidang subjek yang bersangkutan. Dalam melaksanakan tugas ini, koordinator perpustakaan bekerja sama dengan anggota staf pengajar yang oleh ketua jurusan telah ditunjuk sebagai koordinasi departemen. Tugas koordinator departemen mendorong sesama staf pengajar agar mengajukan permintaan untuk bahan perpustakan yang sesuai dengan bidang keahlian mereka, membicarakan masalah atau pertanyaan yang ada sehubungan dengan kebijakan dan prosedur perpustakaan dengan koordinator perpustakaan, dan kurikulum yang mungkin akan berdampak pada jasa perpustakaan. (Septiyantono 2003, 101)

\section{Perpustakaan Perguruan Tinggi}

Perpustakaan Perguruan Tinggi adalah perpustakaan yang berada di lingkungan perguruan tinggi atau sekolah tinggi, akademi dan pendidikan lainnya. Yang pada hakikatnya merupakan badan integral dari suatu perguruan tinggi. Oleh karena itu, perpustakaan berada di lingkungan perguruan tinggi seperti di jurusan, fakultas, lembagalembaga dan pusat- pusat di lingkungan perguruan tinggi, maupun perpustakan di tingkat pusat perguruan tinggi tersebut termasuk kedalam jenis perpustakaan ini. (Rahman 1995, 7)

Perpustakaan Perguruan Tinggi ialah perpustakaan yang terdapat pada perguruan tinggi, badan bawahannya, maupun lembaga yang berafiliasi dengan perguruan tinggi, dengan tujuan utama untuk membantu perguruan tinggi mencapai tujuannya. Tujuan perguruan tinggi di Indonesia dikenal dengan sebutan nama Tri Dharma Perguruan Tinggi (Pendidikan, Penelitian, dan Pengabdian masyarakat) maka perpustakaan perguruan tinggi pun bertujuan dalam membantu melaksanakan ketiga dharma perguruan tinggi. (SulistyoBasuki 1993, 51)

Kegiatan yang melaksanakan seleksi penyiangan adalah pimpinan universitas,dekan, ketua jurusan/program studi, dan dosen. Pembentukn komisi penasihat/pengawas perpustakaan secara khusus juga dapat memilih atau menyarankan agar melanggan terbitan berkala tertentu sebagai salah satu tugasnya. Kegiatan ini biasanya terdiri atas pustakawan, dosen, dekan, dan elemen-elemen lain yang dipandang mampu. Mahasiswa dimungkinkan memberi usulan, tetapi dengan mempertimbangkan keselarasan kebutuhan perkuliahan. (Septiyantono 2003, 83)

\section{E. HASIL PEMBAHASAN}

Dalam mengoptimalkan kegiatan pembelajaran perpustakaan universitas harus menyediakan koleksi yang sesuai dengan kebutuhan masyarakat pengguna jasa perpustakaan. perpustakaan yang baik dan memenuhi standar adalah perpustakaan yang koleksinya relevan dengan kebutuhan masyarakat yang dilayani. Pelayanan sebuah perpustakaan akan dianggap stabil bila suatu perpustakaan memiliki kelengkapan koleksi. Koleksi merupakan unsur terpenting pada sebuah perpustakaan, karena koleksi yang yang dimiliki oleh perpustakaan hanya untuk dimanfaatkan oleh pengguna jasa perpustakaan. Koleksi sendiri mengandung pengertian bahwa semua bahan pustaka yang dikumpulkan, diolah dan disimpan yang bertujuan untuk disebarluaskan kepada masyarakat. (Suikarman 2000)

Koleksi perpustakaan yang telah berkembang akan selalu bertambah namun tidak selalu diikuti oleh perkembangan ruang atau gedung. Penambahan ruang di perpustakaan tidak selalu berubah secara berkala sehingga kemampuan ruang atau gedung untuk menampung koleksi selalu terbatas, sehingga pustakawan harus mencari jalan keluar agar tambahan koleksi selalu dapat tertampung. Salah satunya jalan keluar adalah mengurangi koleksi lama dengan cara mengadakan penyiangan koleksi. (Soeatminah 1992, 127) 
Berdasarkan peraturan pemerintah Republik Indonesia nomor 24 tahun 2014 tentang pelaksanaan Undang-undang 43 tahun 2007 tentang perpustakaan pasal 14 ayat 3, kebijakan pengembangan koleksi mencakup seleksi, pengadaan, pengolahan, dan penyiangan bahan perpustakaan. Merujuk dari peraturan pemerintah di atas maka bahan pustaka yang akan dikelola di perpustakaan sesuai kebijakan pengembangan koleksi yaitu mencakup pengadaan, pengolahan dan penyiangan koleksi perpustakaan.

Kegiatan penyiangan koleksi juga diatur dalam Standar Nasional Perpustakaan (SNP), bahwa kebijakan pengembangan koleksi mencakup dalam seleksi, pengadaan, pengolahan, dan penyiangan bahan perpustakaan yang akan dibahas lebih dalam lagi. Selain itu penyiangan koleksi perpustakaan juga diatur dalam Standar Nasional Indonesia (SNI) menyatakan bahwa penyiangan koleksi adalah kegiatan mengeluarkan koleksi bahan pustaka di perpustakaan yang sudah tidak dipakai lagi dari rak. Dalam menyiangi koleksi harus melihat terlebih dahulu apakah layak untuk disiangi berdasarkan kriteria yang ditetapkan dalam suatu kebijakan. (Ramadani 2017)

Penyiangan bahan pustaka sangat berperan penting dalam kegiatan meningkatkan kualitas koleksi bahan pustaka di perpustakaan. Untuk memastikan mutu koleksi perpustakaan, penyiangan di perpustakaan merupakan kegiatan reassesing atau penilaian kembali atau bisa juga dengan kata lain yaitu evaluasi terhadap kandungan informasi dari sebuah bahan perpustakaan sebelum dilakukan penyiangan. Penilaian kandungan informasi sama halnya dengan kegiatan pengadaan bahan pustaka yang memerlukan pengetahuan dalam mendeteksi kebutuhan informasi pemustaka saat ini. Kebutuhan informasi pemustaka bisa diketahui jika pustakawan melakukan kegiatan analisis kebutuhan pemustaka secara berkesinambungan atau secara berkala. (Fuadah, Rusmono, and Damayanty 2016)

Bahan pustaka yang dapat di weeding adalah :

1. Buku yang umurya sudah tua, isinya sudah kadaluarsa dan tidak cocok lagi untuk dibaca. Mungkin karena buku tersebut sudah ada edisi terbaru yang lebih lengkap dan maknanya lebih mudah dipahami oleh pengguna. Sehingga koleksi yang sudah tua dan isinya kadaluarsa menjadi tidak dipakai lagi oleh pemustaka.

2. Buku yang rusak dan tidak mungkin diperbaiki lagi, karena terlalu seringnnya bahan pustaka tersebut di pinjam oleh pengguna, atau bisa jadi karena isinya sangat menarik jadi membuat pengguna mempunyai fikiran untuk merusaknya dengan cara merobek beberapa halaman agar mendapatkan bahan referensi yang ia inginkan.

3. Buku yang jumlah kopiannya terlalu banyak, sehingga dibutuhkan suatu kegiatan dengan melakukan penyiangan dan tidak semua koleksi di pajang di rak semua.

4. Buku terlarang, buku yang tidak seharusnya ada di rak itu harus dikeluarkan.

5. Lain-lain. (Soeatminah 1992, 127)

\section{Prosedur Penyiangan Bahan pustaka}

Buku-buku yang sudah disiang berdasarkan pedoman penyiangan harus dinyatakan keluar dari koleksi secara resmi, yaitu dengan cara memberikan tanda "dikeluarkan dari koleksi". Tanda tersebut sangat perlu sebagai bukti bahwa pemegang buku berikutnya tidak akan dituduh sebagai pencuri buku perpustakaan. (Soeatminah 1992, 127)

Kartu buku yang ada dalam buku dan kartu katalognya harus dicabut, serta dalam inventaris pada kolom "keterangan" diberi catatan bahwa buku sudah dikeluarkan dari koleksi pada tanggal tertentu. Buku-buku yang disiang, tetapi masih mungkin untuk dimanfaatkan oleh perpustakaan lain, dapat ditawarkan sebagai bahan tukar-menukar atau hadiah. (Soeatminah 1992, 127) 
Menurut Larson sebagaimana dikutip oleh Soetminah (1992), ada enam faktor negatif yang sering merusak kegunaan buku dan menandainya untuk disiangi yaitu :

1. Tidak akurat yaitu menyesatkan dan tidak faktual atau tidak akurat karena adanya penemuan baru, revisi, pemkiran atau teori yang baru atau informasi baru yang kini diterima oleh para profesional dibidang subjek tersebut. Bahkan dalam bidangbidang seperti fisika, yang dianggap cukup mapan, perubahan radikal terjadi akibat dampak dari akurasi dan validitas informasi.

2. Jelek yaitu, jelek atau sudah usang sehingga tidak bisa diperbaiki, faktor meliputi sebagian besar elemen yang berhubungan dengan kondisi fisik item-pakai, kerusakan, noda, kotoran dan rusak yang membuatnya kurang menarik bagi pengguna perpustakaan.

3. Penganti koleksi yaitu buku yang berada di rak diganti dengan edisi yang benar baru atau judul baru atau up to date dalam memberikan informasi terbaru.

4. Tidak memiliki manfaat yaitu, tidak ada manfaat sastra atau ilmiah yang didapat dan masih berada di rak.

5. Tidak relevan yaitu, berarti tidak relevan dengan kebutuhan dan kepentingan pengguna karena berubah dari waktu ke waktu.

6. Informasi yang tepat yaitu, materi yang dapat diperoleh secara cepat melalui tempat lain pinjaman antar perpustakaan lain juga banyak buku yang sekarang tersedia secara online melalui layanan seperti, NetLibrary. Dengan pengecualian buku sejarah lokal dan dokumen regional, hampir semuanya tersedia di tempat lain.

Kemudian mengenai langkah-langkah atau prosedur dalam melakukan penyiangan bahan pustaka dapat dikemukakan dalam gambar sebagai berikut:

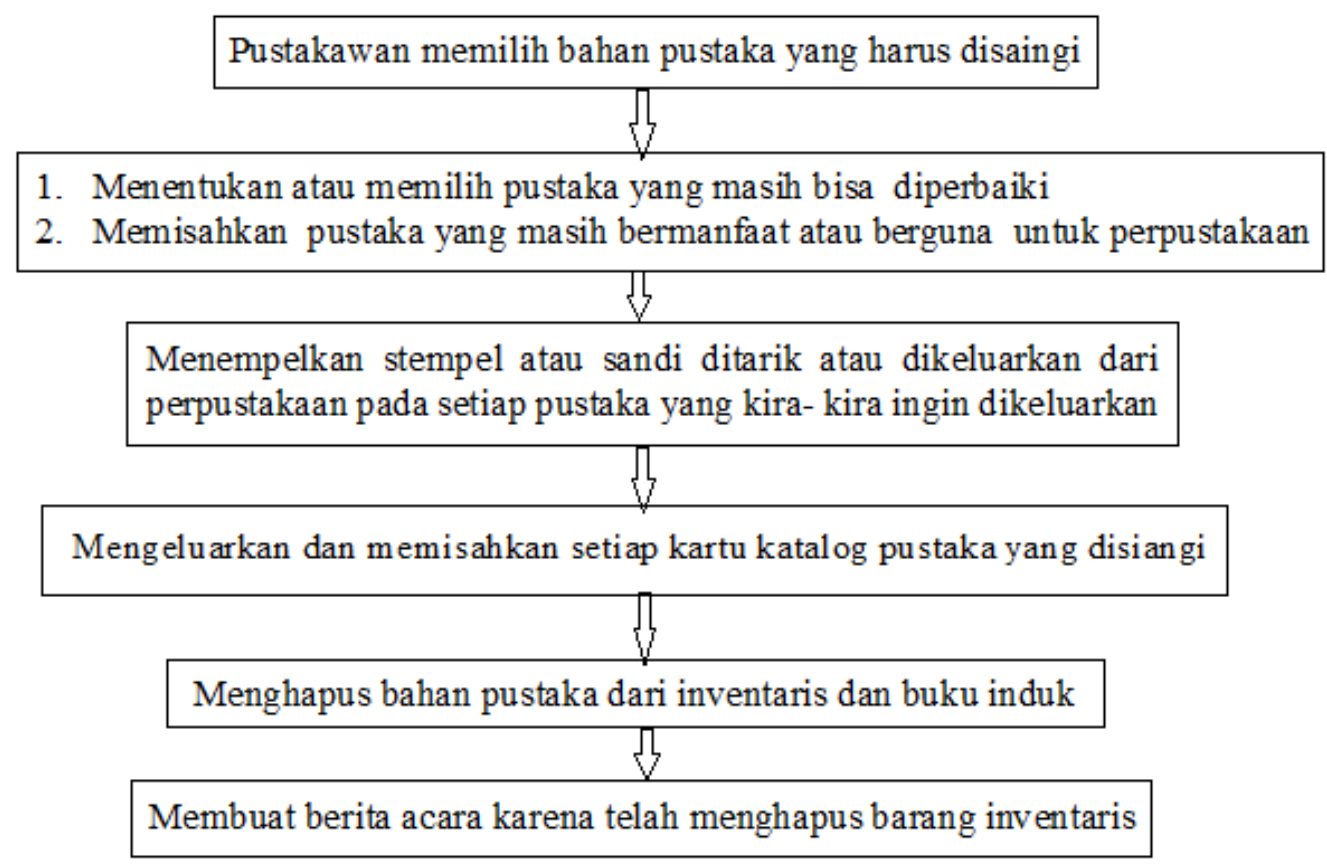

Gambar 1. Proses Penyiangan Bahan Pustaka (Soeatminah 1992, 127) 
Sedangkan fungsi dari penyiangan itu sendiri menurut Pangaribuan (2012) adalah:

1. Menghemat Tempat

Biaya penyediaan ruangan dan rak masih kurang dari biaya yang sebenarnya untuk pembelian rak tambahan untuk pengerakan lebih banyak buku. Suatu perawatan koleksi yang baik akan menghemat biaya pengeseran buku, mengurangi debu dari buku yang tidak satupun digunakan dan membuat ruang lebih banyak.

2. Menghemat Waktu

Menghemat waktu baik bagi pengguna maupun staf dan yang terbaik bagi semua. Rak-rak penuh sesak dengan buku compang-camping dan memerlukan waktu untuk memeriksa tanda-tanda yang tak terbaca. Pengguna yang mencari buku tertentu harus memilih buku yang jelas tidak diinginkan. Staf mencoba untuk mengesampingkan buku yang kembali harus bergeser dan buku tersebut disusun kembali untuk membuat ruang.

3. Membuat Koleksi Lebih Menarik

Dengan memberikan inovasi terbaru yaitu dengan cara mengganti buku rusak, compang-camping, tercoreng dengan penjilidan kembali yang menarik dan bukubuku baru yang tidak menarik menjadi menarik lagi setelah diperbaiki.

4. Meningkatkan Reputasi Perpustakaan

Penyiangan juga dimaksudkan untuk kehandalan dan kemutakhiran dan membangun kepercayaan publik. Pelanggan berharap bahwa bahan pustaka yang dipilih oleh para ahli adalah informasi oyang up-to-date dan dapat diandalkan.

5. Mengetahui Kebutuhan Koleksi

Penyiangan memberikan hasil pemeriksaan berkelanjutan tentang perlunya memperbaiki atau menjilid kembali, pemberitahuan staf perpustakaan untuk buku hilang atau dicuri yang membutuhkan pengganti, dan menjamin hitungan volume yang lebih akurat.

\section{Kendala yang Dihadapi Pustakawan}

Kegiatan penyiangan bukanlah hal yang mudah yang biasa dilakukan siapa saja. Karena proses weeding memerlukan proses yang panjang dan tidak sebentar. Setelah itu dalam pelaksanaannya banyak kendala atau hambatan dari pihak pengelola perpustakaan itu sendiri berkaitan dengan hal ini ada beberapa kendala dalam melaksanakan kegiatan penyiangan yakni sebagai berikut :

Menurut Betriati yang dikutip oleh Kusnanto dalam Rini Arianti (2018), kendala dalam melakukan penyiangan, antara lain:

1. Adanya kebanggaan terhadap koleksi seperti adanya perasaan tidak membuang bahan pustaka dan memang benar- benar bahan koleksinya masih dibutuhkan oleh pengguna.

2. Masih ada anggapan jumlah koleksi menentukan mutu kualitas.

3. Adanya anggapan bahwa penyiangan berlawan dengan tujuan pengadaan atau konsep pembangunan koleksi. Karena keduanya tidak bakalan bisa disatukan antar dua variabel ini.

4. Masih dijumpainya prosedur yang rumit, karena setiap pengeluaran barang harus dilakukan melalui prosedur yang membutuhkan waktu yang lama.

Dalam buku yang berjudul less more than less, karya Donna J. Baumbach dan Linda L. Miller $(2006,4)$ menyebutkan bahwa ada beberapa kendala dalam weeding, yaitu: 
1. Rasa bangga terhadap sebuah koleksi, karena mungkin referensi bahan pustakanya sangat menarik bacaannya terhadap pengguna yang ingin meminjam setelah koleksi melakukan kegiatan penyiangan.

2. Pustakawan atau staf perpustakaan sebelumnya tidak melakukan weeding, sehingga malas untuk melakukannya, ini masuk kedalam masalah kepemimpinan yang dalam suatu pekerjaan kurang tegas didalam suatu kegiatan.

3. Perasaan tidak suka membuang koleksi, yang berakibat terhadap koleksi bahan pustaka yang berada dirak menjadi bertumpuk.

4. Lebih senang memberikan koleksi kepada perpustakaan lain atau orang lain dari pada membuangnya, sehingga koleksi tersebut tidak terbuang sia- sia dan masih bermanfaat bagi orang yang membutuhkan.

5. Koleksi yang banyak akan menunjang proses akreditas, jadi koleksi tetap disimpan.

Dari uraian diatas dapat dinyatakan bahwa perpustakaan memiliki kebanggaan jika mereka memiliki koleksi yang banyak, sehingga kesulitan mereka dalam menarik pengguna yang lebih banyak dalam memenuhi mutu standar tertentu. Padahal kualitas lebih baik dari pada kuantitas, perpustakaan yang baik belum tentu perpustakaan yang besar, karena tingkat dan kualitas pelayanan perpustakaan merupakan hal yang terpenting. Perpustakaan merasa tidak memiliki waktu padahal jika pustakawan memilki waktu untuk memilih buku-buku baru, maka pustakawan juga memiliki waktu untuk menyiangi bukubuku yang tidak lagi berguna untuk koleksi perpustakaan. Image perpustakaan dan kualitas layanan perpustakaan sangat dipertaruhkan, untuk membantu menemukan waktu yang dibutuhkan. Pustakawan memiliki keraguan melakukan penyiangan adanya pengguna yang ingin meminjam koleksi yang sudah disiangi, padahal situasi ini jarang terjadi dan tidak umum terjadi. Bahan pustaka yang telah disiangi, biasanya buku yang belum digunakan dalam lima tahun terakhir tidak mungkin lagi digunakan lima tahun mendatang. Pustakawan menganggap buku tua yang langka bahkan merupakan edisi pertama sangat berharga, padahal walaupun buku tua tersebut telah terbit sebelum tahun 1900, hanya satu dari beberapa kemungkinan. Walaupun buku tersebut merupakan buku yang berharga, sangat jarang menarik bagi kolektor karena perpustakaan menandai buku tersebut dengan nomor akses, barcode, stempel kepemilikan yang membuat buku tersebut jelek.

Faktor-faktor yang menyebabkan keragu-raguan dalam melakukan penyiangan adalah mempertahakan volume koleksi, juga ada ketakutan pada pustakawan bahwa penyiangan menjadi pertanda bahwa pustakawan melakukan kesalahan dalam pemilihan bahan pustaka.

Sebelum penyiangan perlu memeriksa daftar penyeleksian dan pemesanan buku pengganti serta membandingkan dengan buku-buku yang akan disiangi dan disisihkan untuk buku pengganti dengan judul edisi baru dari koleksi bibliografi dan indeks untuk judul baru. Jika koleksi perpustakaan tidak memiliki judul yang direkomendasikan pada area spesifik, pertimbangkan untuk menggunakan bibliografi koleksi untuk mencari judul yang sesuai dengan yang direkomendasikan, kecuali ada permintaan untuk mata pelajaran tertentu, standar koleksi bibliografi, daftar yang direkomendasikan, indeks, database dan daftar bacaan lainnya. Perlu mengatur tampilan rak yang baru dengan buku yang memiliki informasi berkualitas tinggi dan relevan dengan permasalahan dan kepentingan pengguna saat ini harus lebih udah dicari, memberikan tampilan yang menarik. Jika buku tidak diminati masukkan ke bagian buku yang akan di tukar dengan perpustakaan lain atau untuk di sumbangkan atau ditukar, jika dilakukan secara rutin setiap hari, atau bahkan setiap minggu, tinjauan koleksi ini akan memperdalam pengetahuan pustakawan tentang milik perpustakaan, memberi sumber refrensi yang mungkin, mempersiapkan pustakawan untuk 
pemilihan informasi material baru atas dasar penggunaan aktual dan nyata dari kekuatan dan kelemahan. (Arianti 2018, 30)

Masih berkaitan dengan kegiatan penyiangan, Mayrink, Paulo Tarcisio dalam bukunya Weeding in Special Libraries menyebutkan kriteria penyiangan yakni, "Propose criteria for weeding, based on three main factors; physical condition, qualitative value, and quantitative use". Namun demikian kendatipun terdapat beberapa kriteria dalam penyiangan, tetapi keputusan akhir tetap ditentukan oleh pihak pustakawan bersama lembaga penanungnya sesuai dengan kebutuhan serta pendekatan yang meraka gunakan. Kendatipun diakui penyiangan merupakan bagian yang penting dalam proses pengembangan koleksi, namun nampaknya masih terdapat dua pandangan yang bersifat pro dan kontra tentang perlunya penyiangan bahan pustaka. Adapun mengenai kedua pandangan tersebut yakni sebagai berikut:

1. Pandangan Yang Pro:

a. Koleksi harus disiangi atau diweeding agar jumlah yang telah ditentukan dapat terus dipertahankan bahan pustakanya.

b. Ruangan koleksi mempunyai keterbatasan. Koleksi harus terdiri dari bukubuku yang paling mungkin digunakan atau dibutuhkan pemakai.

c. Penyiangan dapat meningkatkan akses ke koleksi.

2. Pandangan Yang Kontra:

a. Buku merupakan catatan peradaban yang harus selalu dilestarikan.

b. Penyiangan merupakan suatu pekerjaan yang sulit dilakukan, karena harus dilakukan orang-orang yang benar-benar ahli.

c. Masih adanya anggapan bahwa banyaknya koleksi akan menentukan kehebatan suatu perpustakaan. ( Rusmana, Agustini d, and Winoto 2015)

Apabila di atas dijelaskan tentang pandangan yang pro dan kontra tentang penyiangan bahan pustaka, maka jika telah diputuskan penyiangan perlu dilakukan ada beberapa pendekatan yang biasa digunakan. Mengenai hal ini Line, mengemukakan beberapa pendekatan yang biasa dipakai sebagai pedoman untuk penyiangan (weeding) koleksi yakni:

a. Subject judgement atau penilaian suatu subjek, menilai setiap bahan pustaka sebelum ingin di siang, karena untuk melakukan kegiatan ini memang harus benar-benar dalam menyeleksi bahan pustaka yang ingin di pisahkan.

b. Age, usia, jika usia bahan pustaka sudah terlalu lama maka koleksi tersebut butuh di siang, mungkin karena sudah ada koleksi terbitan terbaru yang lebih mudah dipahami oleh pengguna dan buku yang memang sudah lama biasanya mempunyai bentuk fisik yang sudah rusak karena termakan usia seperti ada halaman yang hilang, fisiknya udah hancur dimakan rayap dan masih banyak lagi masalah jika bahan pustaka tersebut sudah dimakan usia.

c. Date of acquisition, tanggal aquisisi yaitu pembelian bahan pustaka antar perpustakaan sehingga melakukan kerja sama antar perpustakaan.

d. Use/circulation, sirkulasi suatu tempat dimana pemustaka ingin melakukan interaksi kepada pustakawan

e. Shelf time period, atau waktu sebelum melakukan penyiangan ada baiknya perpustakaan mempunyai kebijakan dalam melakukan kegiatan penyiangan agar menjadi lebih optimal dan koleksinya pun tidak berantakan atau menumpuk di rak. ( Rusmana, Agustini d, and Winoto 2015) 


\section{B. Kesimpulan}

Penyiangan atau weeding adalah upaya mengeluarkan sejumlah koleksi dari perpustakaan karena telah dianggap tidak relevan lagi, terlalu banyak jumlah eksemplarnya, sudah ada edisi baru, atau koleksi itu termasuk terbitan yang dilarang. Sehingga koleksi ini dapat ditukarkan dengan koleksi perpustakaan lain, dihadiahkan, atau dihancurkan untuk pembuatan kertas lagi. Prosedur yang dilakukan dalam penyiangan yaitu Pustakawan menentukan buku yang perlu disaingi, menyisihkan pustaka yang masih bermanfaat untuk perpustakaan, Membubuhkan stempel atau sandi ditarik atau dikeluarkan dari perpustakaan pada setiap pustaka yang dikeluarkan, Mencabut dan menyisihkan setiap kartu katalog pustaka yang disiangi, Menghapus pustaka dari inventaris dan buku induk, Membuat berita acara penghapusan barang inventaris. Pustakawan memiliki keraguan melakukan penyiangan adanya pengguna yang ingin meminjam koleksi yang sudah disiangi, padahal situasi ini jarang terjadi dan tidak umum terjadi. Bahan pustaka yang telah disiangi, biasanya buku yang belum digunakan dalam lima tahun terakhir tidak mungkin lagi digunakan lima tahun mendatang.

\section{DAFTAR PUSTAKA}

Arianti, Rini. 2018. "Evaluasi Penyiangan Koleksi Dengan Menggunakan Metode CREW Pada Perpustakaan Universitas Medan Area (UMA).” Skripsi, Medan: Universitas Sumatera Utara. http://repositori.usu.ac.id/handle/123456789/4391.

Baumbach , and Miller. 2006. Less Is More: A Practical Guide to Weeding School Library Collection. Chicago: American Library Association.

Cahyono, Teguh Yudi. 2017. "Penyiangan: Sebuah Strategi Untuk Manajemen Koleksi Perpustakaan Yang Efektif Pada University of Ghana Medical School, Korle-Bu." UPT Perpustakaan Universitas Negeri Malang. 2017. http://lib.um.ac.id/wpcontent/uploads/2017/07/Penyiangan-Sebuah-Strategi-untuk-Manajemen-Koleksi-

Perpustakaan-yang-Efektif-pada-University-of-Ghana-Medical-School.pdf.

Fuadah, Rahmi Nurul , Doddy Rusmono, and Damayanty. 2016. "Analisis Penyiangan KoleksiGrey Literature Pada Perpustakaan Universitas Pendidikan Indonesia." Edulibinfo 3 (2): 156-68.

Lasa HS. 2006. Manajemen Perpustakaan. Yogyakarta: Gama Media.

Pangaribuan, Syakirin. 2012. Manual Penyiangan Koleksi Perpustakaan Modern. Medan: Fakultas Ilmu Budaya USU.

Rahayu, Astuni, and Elva Rahmah. 2013. “Kegiatan Penyiangan Bahan Pustaka (Weeding) Di Perpustakaan Universitas Negeri Padang." Jurnal Ilmu Informasi Perpustakaan Dan Kearsipan 2 (1): 12-19. https://doi.org/ https://doi.org/10.24036/2285-0934.

Rahman, Abdul . 1995. Manajemen Perpustakaan Perguruan Tinggi. Jakarta: Universitas Terbuka.

Ramadani, Fitra. 2017. "Prosedur Penyiangan Koleksi Di Perpustakaan Usman Bin Affan Universitas Muslim Indonesia Makasar." Skripsi, Makassar: Universitas Islam Negeri Alauddin . http://repositori.uin-alauddin.ac.id/7877/.

Rusmana, Agus, Ninis Agustini d, and Yunus Winoto. 2015. "Beberapa Faktor Yang Mempengaruhi Para Pengelola Perpustakaan Terhadap Pelaksanaan Kegiatan Penyiangan (Weeding) Bahan Pustaka." Sosiohumaniora 3 (3): 199. https://doi.org/https://doi.org/10.24198/sosiohumaniora.v3i3.5199. .

Septiyantono, Tri . 2003. Dasar- Dasar Ilmu Perpustakaan Dan Informasi. Yogyakarta: Jurusan Ilmu Perpustakaan dan Informasi, Fakultas Adab. 
Soeatminah. 1992. Perpustakaan Kepustakawanan, Dan Pustakawan. Yogyakarta: Kanisius.

Suikarman, Rahmat Nata Djumaena . 2000. Pedoman Umum Pengelolaan Perpustakaan Perguruan Tinggi. Jakarta: Pernas.

Sulistyo-Basuki. 1993. Pengantar Ilmu Perpustakaan. Jakarta: Gramedia Pustaka Utama. Sutarno NS. 2003. Perpustakaan Dan Masyarakat. Jakarta: Yayasan Obor Indonesia. Suwarno, Wiji. 2010. Perpustakaan Dasar Kepustakaan. Bogor: Ghalia Indonesia. 